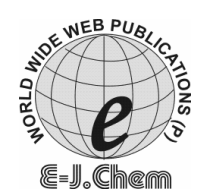

http://www.e-journals.net
ISSN: 0973-4945; CODEN ECJHAO

E-Journal of Chemistry

2008, 5(S2), 1117-1122

\title{
Validation and Stability Indicating RP-HPLC Method for the Determination of Sildenafil Citrate in Pharmaceutical Formulations and Human Plasma
}

\author{
B. PRASANNA KUMAR REDDY* and Y. RAMANJANEYA REDDY \\ *Department of Quality Control and Quality Assurance, \\ Smilax Laboratories limited, Hyderabad-500055, A.P, India. \\ Department of Biology, GVK Biosciences, Hyderabd, A.P, India, \\ b_p_reddy2002@yahoo.com
}

Received 17 March 2008; Accepted 10 May 2008

\begin{abstract}
A simple, selective, accurate reverse phase-high performance liquid chromatographic (RP-HPLC) method was developed and validated for the analysis of sildenafil citrate in pharmaceutical formulations. Chromatographic separation achieved isocratically on a $\mathrm{C}_{18}$ column (Use Inertsil $\mathrm{C}_{18}, 5 \mu, 150 \mathrm{~mm} \times 4.6 \mathrm{~mm}$ ) utilizing a mobile phase of acetonitrile/phosphate buffer (70:30, v/v, $\mathrm{pH} 7.0)$ at a flow rate of $0.8 \mathrm{~mL} / \mathrm{m}$ with $\mathrm{UV}$ detection at $228 \mathrm{~nm}$. The retention time was 4.087 . The method is accurate $(99.15-101.85 \%)$, precise (intra-day variation $0.13-1.56 \%$ and inter-day variation $0.30-1.60 \%)$ and linear within range $0.1-30 \mu \mathrm{g} / \mathrm{mL}\left(\mathrm{R}^{2}=0.999\right)$ concentration and was successfully used in monitoring left over drug. The detection limit of sildenafil citrate at a signal-to-noise ratio of 3 was $1.80 \mathrm{ng} / \mathrm{mL}$ in human plasma while quantification limit in human serum was $5.60 \mathrm{ng} / \mathrm{mL}$. The proposed method is applicable to stability studies and routine analysis of sildenafil citrate in pharmaceutical formulations as well as in human plasma samples.
\end{abstract}

Keywords: Sildenafil citrate, RP-HPLC method, Validation, Tablet dosage form

\section{Introduction}

Sildenafil citrate is designated chemically as 1-[[3-(6, 7-dihydro-7-oxo-3-propyl-1Hpyrazolo [4, 3- $d$ ] pyrimidin-5-yl)-4-ethoxyphenyl] sulfonyl]-4-methylpiperazine and it is a popularly known as Viagra (Figure 1). It is a novel oral agent for the treatment of penile erectile dysfunction ${ }^{1,2}$. It is an active inhibitor of the type $V$-cyclic guanosine monophosphate (cGMP) specific phosphodiesterase on penile erectile activity, and causes cGMP to accumulatecorpus cavernosum ${ }^{3-6}$. The structural formulae is $\mathrm{C}_{22} \mathrm{H}_{30} \mathrm{~N}_{6} \mathrm{O}_{4} \mathrm{~S}$. It is an ampholyte 
with pKa value 4 (pirydinium ion) and 8.8 (benzimidazole). Sildenafil citrate is twice as soluble in methanol as in water. Its solubility decreases with $\mathrm{pH}$ up to 9 when it starts to increase again. A few methods based on HPLC were reported for the determination of sildenafil citrate in biological and pharmaceutical products. A reverse phase HPLC method using acetonitrilephosphate buffer water $(28: 4: 68 \mathrm{v} / \mathrm{v} / \mathrm{v})$ with detection at $230 \mathrm{~nm}$ was utilized for the simultaneous determination for sildenafil and its metabolite (UK-103, 320) using the automated sequential trace enrichment of dailysates ${ }^{7}$. Reverse phase HPLC method using $70 \mathrm{mM}$ potassium phosphate monobasic buffer of $\mathrm{pH} 3.0$ containing $100 \mathrm{mM}$ triethylamine: acetonitrile $(7: 3 \mathrm{v} / \mathrm{v})$ as the mobile phase at $225 \mathrm{~nm}$ for the separation of sildenafil citrate formed due to oxidation ${ }^{8}$. RP-HPLC method for the determination of sildenafil citrate by using Lichrospher $\mathrm{C}_{18}$ column with wateracetonitrile as the mobile phase and UV detection ${ }^{9}$ at $245 \mathrm{~nm}$. A reverse phase HPLC method for the determination of its related substances in commercial formulations and tablets was reported ${ }^{10}$. The method was developed utilizing a monolithica silica column and an isocratic elution of acetonitrile: water and detection ${ }^{11}$ at $292 \mathrm{~nm}$ with a flow rate of $2.0 \mathrm{~mL} / \mathrm{m}$.<smiles>CCCc1nn(C)c2c(=O)[nH]c(-c3cc(S(=O)(=O)N4CCN(C)CC4)ccc3OCC)nc12</smiles>

\section{Experimental}

Figure 1. Structure of sildenafil citrate drug

A high performance liquid chromatograph system, with LC solutions data handling system (Shimadzu-LC 2010) with an auto sampler was used for the analysis. The data was recorded using LC 2010 solutions software. The purity determination performed on a stainless steel column $150 \mathrm{~mm}$ long, $4.6 \mathrm{~mm}$ internal diameter filled with octadecyl silane chemically bonded to porous silica particles of $5 \mu \mathrm{m}$ diameter (Inertsil $\mathrm{C}_{18}, 5 \mu, 150 \mathrm{~mm} \times 4.6 \mathrm{~mm}$, make: Shimadzu ltd, Japan) with the mobile phase containing acetonitrile and phosphate buffer in the ratio of 70:30 (v/v pH 7.0) at ambient temperature. Flow rate was kept at 0.8 $\mathrm{mL} / \mathrm{min}$, and the elution was monitored at $228 \mathrm{~nm}$.

Sildenafil citrate working standard used from Smilax Laboratories Limited. For the estimation of sildenafil citrate in bulk and commercial formulations of sildenafil brand (Scilla, Scilla Biotechnologies Pvt Ltd), 20 tablets were obtained from retail pharmacies. Each tablet was labeled contain $50 \mathrm{mg}$ of sildenafil citrate and had an expiry of not less than 365 days at the time of study. HPLC grade Sodium dihydrogen phosphate $\left(\mathrm{NaH}_{2} \mathrm{PO}_{4}\right)$ Disodium hydrogen phosphate $\left(\mathrm{Na}_{2} \mathrm{HPO}_{4}\right)$, Acetonitrile- procured from Merck, India. High pure water was prepared by using Millipore Milli Q plus purification system

\section{Preparation of mobile phase}

Mobile phase was prepared by mixing $700 \mathrm{~mL}$ of acetonitrile with $300 \mathrm{~mL}$ of phosphate buffer and its $\mathrm{pH}$ adjusted to 7.0. The mobile phase was sonicated for $15 \mathrm{~min}$ and then it was filtered through a $0.45 \mu$ membrane filter paper

Preparation of stock and standard solutions

Accurately weighed $25 \mathrm{mg}$ of test sample into a clean dry $50 \mathrm{~mL}$ volumetric flask, dissolve and dilute to the mark with mobile phase. Mark this solution as sample solution. This solution contains $0.5 \mathrm{mg} / \mathrm{mL}$ of sample.Qualified working standard of sildenafil citrate is used to carry out 
validation exercise. The potency of working standard is $99.68 \%$. With the optimized chromatographic conditions, a steady baseline was recorded, the standard solution was injected and the chromatogram was recorded. This procedure was repeated for the sample solution.

\section{Method validation}

The method was validated for the parameters like specificity, range and linearity, limit of detection (LOD), limit of quantitation (LOQ), accuracy, and precision. In addition, system suitability parameters were also calculated. To demonstrate specificity in the presence of excipients used in formulation, sildenafil citrate was spiked (at approximately $25 \mu \mathrm{g} / \mathrm{mL}$ ) in drug product, chromatogram was observed and compared with that of raw material. To evaluate the linearity, the LOD and LOQ of the method in reference drug and in serum, different serial dilutions $(0.0990,0.190,0.80,1.50,3.12,6.30,12.50$ and $25 \mu \mathrm{g} / \mathrm{mL})$ were prepared from the standard stock solutions in $25 \mathrm{~mL}$ volumetric flasks and volume made up with diluent which is mixture of 70:30 acetonitrile \& methanol. The samples were injected $(10 \mu \mathrm{L})$ and signals from the samples were recorded at 2.02 minute which was compared with those of blank. LOD and LOQ values were calculated as signal-to-noise ratio of 3:1 and 10:1 respectively. To determine accuracy of the method, working standard of sildenafil citrate was prepared in triplicate at three concentration levels $(10,20$ and $25 \mu \mathrm{g} / \mathrm{mL})$ and analyzed. Repeatability of the method was checked by analyzing six replicate samples of sildenafil citrate (at the $100 \%$ concentration level) and calculating relative standard deviation (\%RSD). To determine intermediate precision, standard solutions of sildenafil citrate at eight concentration levels were analyzed three times within the same day (intra-day variation) and three other days (inter-day variation).

\section{Assay in formulations}

In case of marketed formulations, five accurately weighed tablets were crushed to a fine powder and an amount equivalent to $10 \mathrm{mg}$ of sildenafil citrate was added into different $100 \mathrm{~mL}$ volumetric flasks and volume was made up with acetonitrile and methanol mixture. The samples were filtered through a $0.45-\mu \mathrm{m}$-membrane filter; different serial dilutions $(3.12,6.20,12.30,25 \mu \mathrm{g} / \mathrm{mL})$ were made from this solution in $25 \mathrm{~mL}$ volumetric flask and were injected for HPLC analysis.

\section{Assay in serum}

One volume of plasma was deproteinated by nine volume of acetonitrile and filtered through 0.45 $\mu \mathrm{m}$ Millipore filter paper that was used to make serial dilution of sildenafil citrate $(0.0970 \mu \mathrm{g} / \mathrm{mL}$ to $25 \mu \mathrm{g} / \mathrm{mL}$ ). Three replicates of each dilution were injected to HPLC system and linearity was evaluated. Repeatability of the method was checked by analyzing six replicate samples of sildenafil citrate (at the $100 \%$ concentration level) and calculating relative standard deviation (\%RSD).

\section{Results and Discussion}

For validation of analytical methods, the guidelines of the International Conference on the Harmonization of Technical Requirements for the Registration of Pharmaceuticals for Human Use [ICH 1996] $]^{12}$ have recommended the accomplishment of accuracy tests, precision, specificity, linearity of the method

System suitability

The HPLC system was equilibrated with the initial mobile phase composition, followed by 10 injections of the same standard. These 10 consecutive injections were used to evaluate the system suitability on each day of method validation.

The system suitability parameters including capacity factor $>2$, resolution $>3$ and asymmetric factor $<2$. All parameters were satisfactory with good specificity for the stability assessment of sildenafil citrate. Theoretical plates of the column were $>3000$. 


\section{Accuracy}

The accuracy of an analytical method is the closeness of test results obtained by that method to true value. In case of the assay of a drug in a formulated product, accuracy may be determined by application of the analytical method to synthetic mixtures of the drug product components to which known amount of analyte has been added within the range of method. If it is not possible to obtain samples of all drug product components, it may be acceptable to add known quantities of the analyte to the drug product (i.e. "to spike").In our studies, the later technique was adopted and sildenafil citrate was spiked in drug product. The result of accuracy given in (Table 1) revealed that the method was found accurate for all above purposes.

Table 1. Accuracy/recovery of sildenafil citrate

\begin{tabular}{cccc}
\hline Parameters & Conc, $\mu \mathrm{g} / \mathrm{mL}$ & \% Recovery & $\%$ RSD \\
\hline Assay & 10 & 96.02 & 1.70 \\
(Spiking & 20 & 101.52 & 4.80 \\
method) & 25 & 95.15 & 4.60 \\
\hline \multirow{2}{*}{ Assay } & 6.30 & 99.18 & 0.5 \\
& 12.30 & 100 & 1.5 \\
& 25 & 99.99 & 0.3 \\
\hline \multirow{2}{*}{ Assay } & 12.30 & 100 & 0.5 \\
(in serum) & 6.20 & 100 & 1.2 \\
& 3.12 & 100 & 0.8 \\
\hline
\end{tabular}

\section{Precision}

Precision is the degree of reproducibility or repeatability of the analytical method under normal operating conditions. The method passed the test for repeatability as determined by $\%$ RSD of the area of the peaks of six replicate injections at $100 \%$ test concentration. The results of intra-and inter-day variation are shown in (Table 2).

Table 2. Intermediate precision of the method

\begin{tabular}{cccc}
\hline \multirow{2}{*}{$\begin{array}{c}\text { Concentration } \\
\mu \mathrm{g} / \mathrm{mL}\end{array}$} & \multicolumn{2}{c}{ Assay in formulation } & Serum \\
\cline { 2 - 4 } & $\begin{array}{c}\text { Intra-day variation } \\
\text { \%RSD }\end{array}$ & $\begin{array}{c}\text { Inter-day variation } \\
\text { \%RSD }\end{array}$ & $\begin{array}{c}\text { Intra-day variation } \\
\text { \%RSD }\end{array}$ \\
\hline 0.099 & 0.13 & 0.90 & 4.12 \\
0.19 & 0.35 & 0.33 & 0.08 \\
0.80 & 0.40 & 1.60 & 2.70 \\
1.50 & 0.85 & 1.08 & 3.20 \\
3.12 & 0.26 & 0.20 & 1.15 \\
12.5 & 1.65 & 0.80 & 0.40 \\
25 & 0.25 & 1.08 & 3.30 \\
\hline
\end{tabular}

\section{Range and linearity}

The linearity of an analytical method is its ability to elict test results that are directly, or by a well-defined mathematical transformation, proportional to the concentration of analyte in samples within a given range. The linearity of the method was observed with in the expected concentration range demonstrating its suitability for analysis. The correlation coefficient $\left(\mathrm{r}^{2}\right)$ was found to be 0.999 and value of intercept was less than 25 of the response of $100 \%$ of the test concentration in all the cases indicating functional linear relationship between the concentration of analyte and area under the peak. 


\section{Limits of detection and quantitation}

The detection limit (LOD) is the lowest amount of an analyte in a sample that can be detected, but not necessarily quantitated, under the stated experimental conditions. It may be expressed as a concentration that gives a signal-to-noise ratio of 2:1 or 3:1 (ICH Q2B guidelines, 1997, FDA, Guidance for Industry 2000) ${ }^{13}$. The lower limit of detection for sildenafil citrate is 2.40 $\mathrm{ng} / \mathrm{mL}$ in reference material and formulation and $1.70 \mathrm{ng} / \mathrm{mL}$ serum. Limit of Quantitation (LOQ) is the lowest amount analyte in a sample that can be determined with acceptable precision and accuracy under the stated experimental conditions. A signal-to-noise ratio of 10:1 can be taken as LOQ of the method (USP 2004). The LOQ values were found to be 8.15 $\mathrm{ng} / \mathrm{mL}$ for raw material, formulations and $5.70 \mathrm{ng} / \mathrm{mL}$ for serum.

\section{Specificity}

Specificity is the ability to assess unequivocally the analyte in the presence of components that may be expected to be present in the sample matrix (USP 2004). For demonstrating the specificity of the method for drug formulation the drug was spiked and the representative chromatogram (Figure 2). The excipiants used in different formulation products did not interfere with the drug peak and thus, the method is specific sildenafil citrate. To further confirm the specificity of the method, UV scans of spiked drug were taken in the range 200$400 \mathrm{~nm}$ and no significant change was found by comparing the absorbance of pure drug and spiked drug at the analytical wavelength of drug.

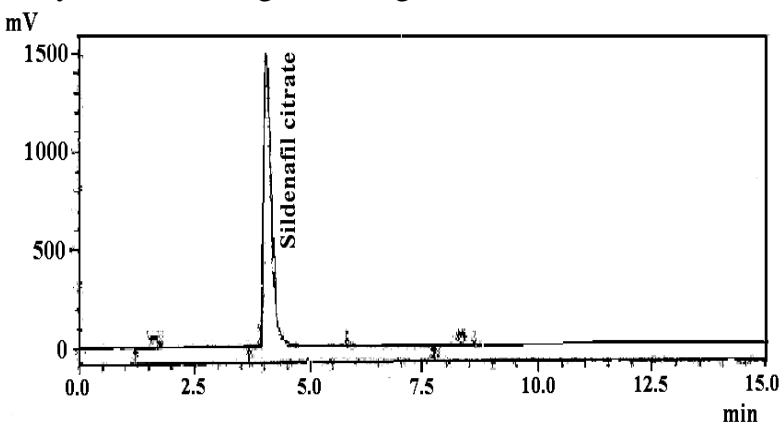

\section{Stability Studies \\ Stability of sample in mobile phase}

Figure 2. Chromatogram of sildenafil citrate drug

The stability of sample solution (Sildenafil citrate) in mobile phase was demonstrated by injected the sample solution at different time intervals viz. 0, 3, 6, 9, 12 and 24 hours of time intervals. Up to 9 hours, no degradants were observed in the chromatogram. However, after 9 hours the chromatographic peak area of sildenafil citrate decreased insignificantly. Hence, the sample solution was stable at least for 9 hours after its preparation. Interestingly, after 9 hours, when samples were stored at $20^{\circ} \mathrm{C}$ under laboratory light conditions, significant rise in the peak areas were observed. Thus, it would be preferable that the sample solution is to be injected before 9 hours of its preparation.

\section{Hydrolysis}

Individually, $5 \mathrm{~mL}$ of the standard solution was transferred to a $10 \mathrm{~mL}$ distillation flask and boiled for $1 \mathrm{~h}$ at $80^{\circ} \mathrm{C}$ after adding : (a) $5 \mathrm{~mL}$ of water for neutral hydrolysis (b) $5 \mathrm{~mL}$ of $0.1 \mathrm{~N}$ $\mathrm{HCl}$ for acid hydrolysis (c) $5 \mathrm{~mL}$ of $0.1 \mathrm{~N} \mathrm{NaOH}$ for basic hydrolysis. Before the analysis, (b) and (c) solutions were neutralized. For chemical oxidation to $5 \mathrm{~mL}$ of the standard solution, 100 $\mu \mathrm{L}$ of $30 \% \mathrm{H}_{2} \mathrm{O}_{2}$ solution $(v / v)$ were added and mixed. The solution was left at room temperature for 1 hour in the dark. 


\section{Photochemical degradation}

The photochemical stability of the sildenafil citrate was studied by exposing the methanolic stock solution to direct sunlight for $8 \mathrm{~h}$ (from $9 \mathrm{AM}$ to $5 \mathrm{PM}$, at $20^{\circ} \mathrm{C}$ ).

Thermal stress (test sample exposed to sunlight)

Transfer about 2 to $3 \mathrm{gm}$ of sample into a clean dry watch glass and spread evenly. Expose to sunlight for 10 hours. After the sample got exposed to prescribed time, weigh accurately $25 \mathrm{mg}$ of sample into a clean dry $50 \mathrm{~mL}$ volumetric flask, dissolve and dilute to the mark with mobile phase and exposed to sunlight.

Stability-indicating methods have received considerable attention for the determination of a vast number of drugs ${ }^{14-17}$. The international Conference on Harmonization (ICH) guideline entitled "Stability Testing of New Drug Substances and Products" requires the stress testing to be carried out to elucidate the inherent stability characteristics of the active substances ${ }^{18}$. Susceptibility to oxidation is one of the required tests. The hydrolytic and photolytic stabilities are also required. An ideal stability-indicating method is one that quantifies the drug present and also resolves its degradation products. This study was carried out by employing the following tests: hydrolysis (neutral, acidic and basic), chemical oxidation, photolysis and thermolysis. No decomposition was observed when the sildenafil citrate was exposed to sunlight, temperature, UV; whereas significant change i.e., decrease of assay about 25 to $30 \%$ observed when sample was treated with $0.1 \mathrm{~N}$ $\mathrm{NaOH}$ and $0.1 \mathrm{~N} \mathrm{HCl}$. The sample treated with $3 \% \mathrm{H}_{2} \mathrm{O}_{2}$ was almost completely degraded

\section{References}

1. Boolell M, Allen M J, Ballard S A, Geti-Attee S, Muirhead G J, Naylor A M, Osterloh H and Jingell C, Int J Import Res., 1996, 8, 47.

2. Morales A, Gingell C, Collins M, Wicker P A and Osterloh I H, Int J Import Res., 1998, 10, 69-73.

3. Boolell M, Gepi-Attee S, Gingell J C and Allen M J, Br J Urol., 1996, 78, 257.

4. Turko I V, Ballard S A, Francis S H and Corbin J D, J Mol Pharmacol., 1999, 56, 124

5. Lowentritt B H, Scardino P T, Miles B J, Orejucla F J, Schatte E C, Slawin K M, Elliot S P and Kim E D, J Urol., 1999, 162, 1614.

6. Brock G, Sildenafil Citrate (Viagra), Drugs Today, 2000, 36, 125-134.

7. Cooper J D H, Muirhead D C, Taylor J E and Baker P R, J Chromatogr., B, 1997, 701,87.

8. Martel A M, Graul A, Rabasseda X and Castaner R, Drugs Fut., 1997, 22, 138.

9. Dinesh N D, Vishukumar B K, Nagaraja P, Gowda N M M and Rangappa K S, J Pharm Biomed Anal., 2002, 29, 743.

10. Draghmeh N, Al-Omari M, Badwan A A and Jaber A M, J Pharm Biomed Anal., $2001,25,483$.

11. Hassan Y, Aboul-Enein, Mohamed M and Hefnawy, J Liquid Chromatogr. \& Related Technologies, 2003, 26, 2897-2908.

12. ICH of Technical Requirements for the Registration of Pharmaceutical for Human Use (ICH) Q2B, 1996. Validation of Analytical Procedures, Methodology.

13. ICH Q2B, Validation of Analytical Procedures, Methodology, May 1997.

14. Avarez-Lueje A., Pujol S, Squella J A and Nunez Vergara L, J Pharm Biomed Anal., 2003, 31, 1-9.

15. Abdul-Fattah A M and Bhargava H N, J Pharm Biomed Anal., 2002, 29, 901-908.

16. Lambropouls J, Spanos G A and Lozaridis V N, J Pharm Biomed Anal., 1999, 19, 793.

17. Bebawy L, Anal Lett., 2003, 36, 1147-1161.

18. ICH, Q1A Stability Testing of New Drug Substances and Products. October 1993; International Conference on Harmonization. Geneva. 


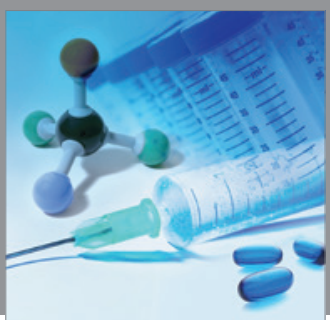

International Journal of

Medicinal Chemistry

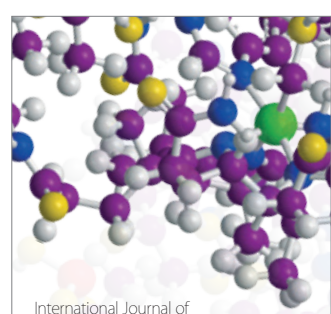

Carbohydrate Chemistry

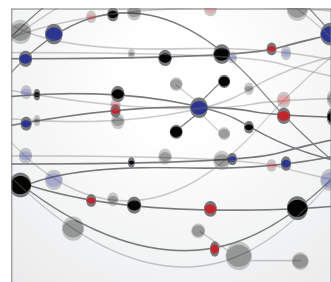

The Scientific World Journal
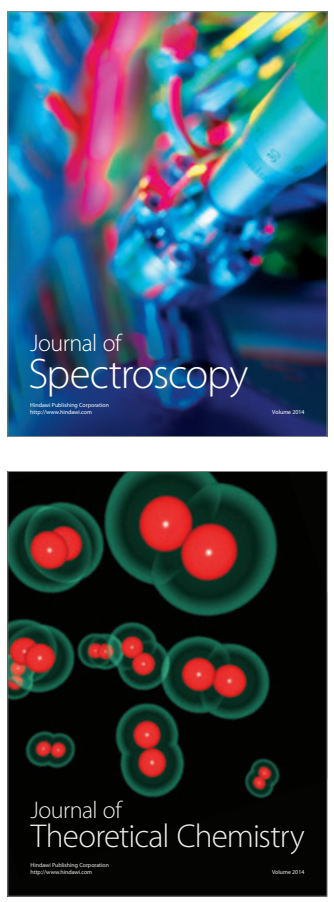
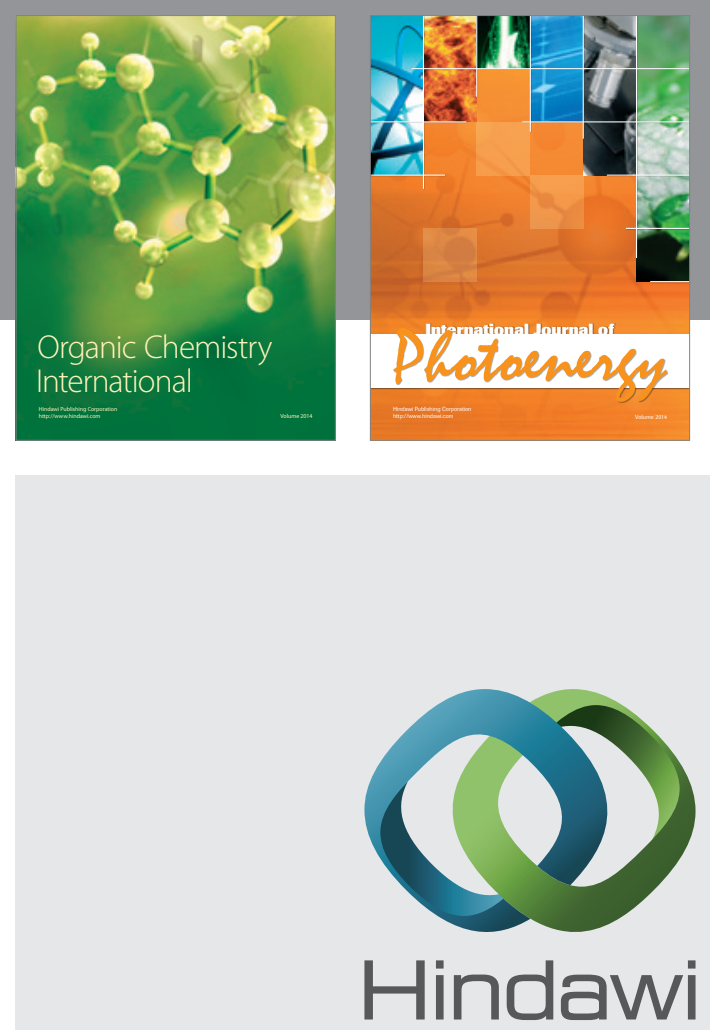

Submit your manuscripts at

http://www.hindawi.com
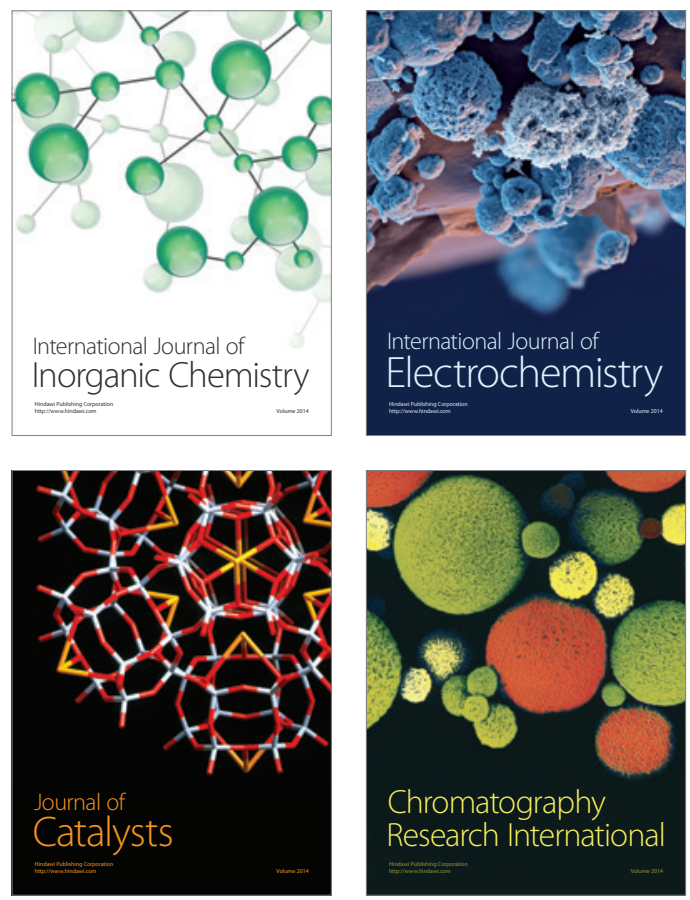
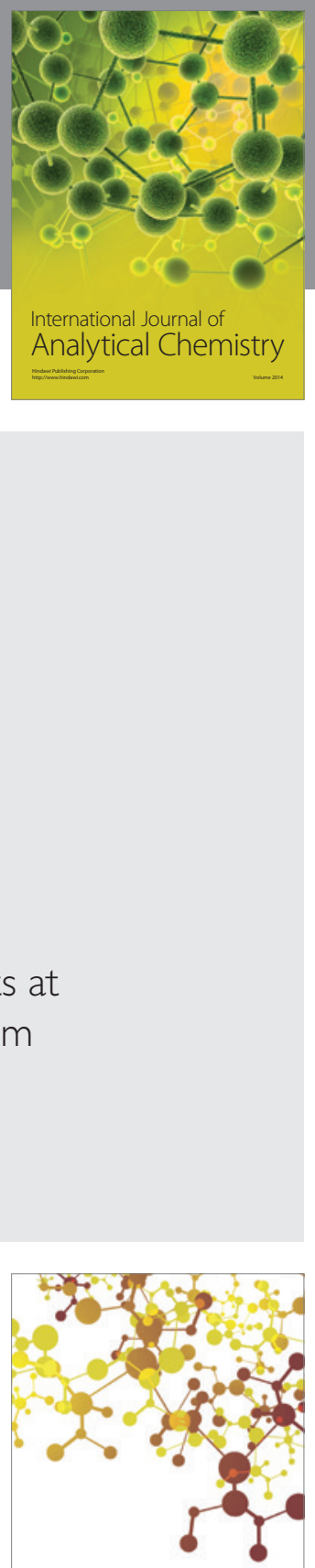

Journal of

Applied Chemistry
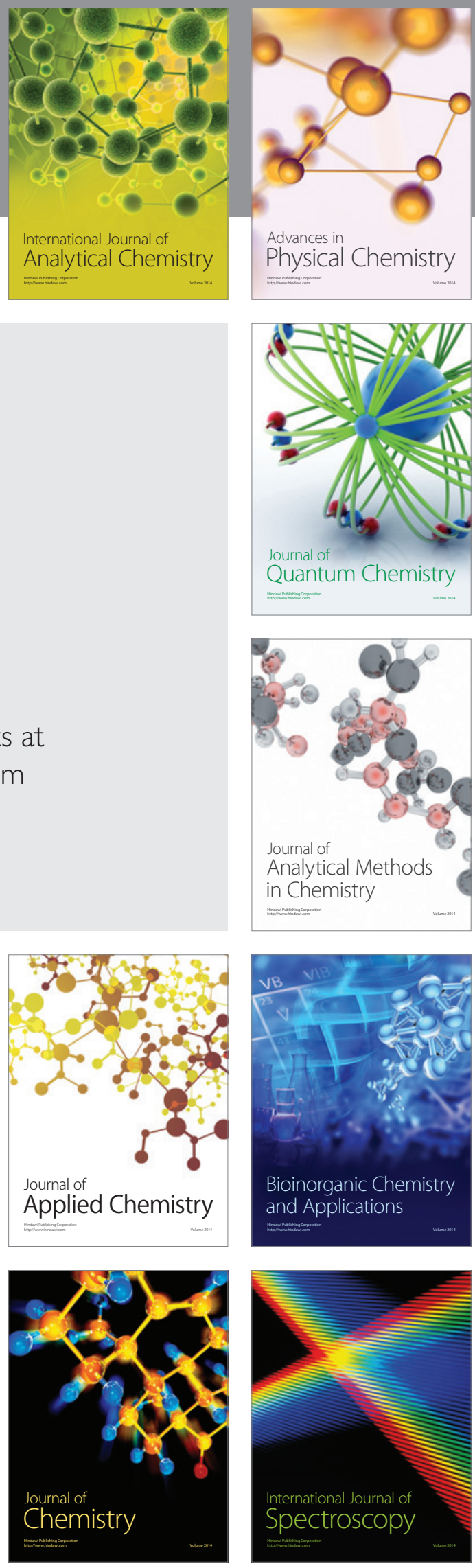